\title{
Educational Values in a Script "Ngelmi Karoyalan" - A Local Wisdom of Javanese Community
}

\author{
Sri Wahyu Widayati \\ Universitas Negeri Surabaya \\ Surabaya, Indonesia \\ sriwahyu@unesa.ac.id
}

\author{
Sukarman \\ Universitas Negeri Surabaya \\ Surabaya, Indonesia \\ sukarman@unesa.ac.id
}

\begin{abstract}
This study aims to reveal the educational values in "Ngelmi Karoyalan" script to be actualized to the community through journals or textbooks. The method used in this study is analytic descriptive for the old literature. The theories which are used include philology, semiotics, and hermeneutics. Based on the analysis, it is found that "Ngelmi Karoyalan" script contains 11 religious educational values; 9 educational moral values; 3 social educational values; and 7 culture educational values. The local wisdoms in "Ngelmi Karoyalan" script are: Javanese community do not like people who boast their good looking and wealth; Javanese community really hate people who spend money for hiring women; Masher men will suffer syphilis and become destitute in their old ages; No one wants to be occupied; Men, who seek women with money, will not get true love; Women who are already "depraved" will be difficult to be pulled socks up and forbidden to be approached; Javanese community really hate women who work as bitches; Javanese community do not like dandy and lazy women. Those Javanese local wisdoms are appropriate to be applied to Javanese community's lives nowadays.
\end{abstract}

Keywords-Karoyalan; educational values; local wisdom; Javanese community

\section{INTRODUCTION}

Indonesian people cannot escape from the influence of information globalization that happens in the world, however, it gives positive and negative impacts. The positive impact is Indonesian people can easily access news which can add knowledge and insights, while the negative impact is that nation moral degradation of young generations can happen since the young generations lack of cultural insight. In this case, they are more familiar with foreign cultures than local cultures. This also happen to Javanese community as the most numerous ethic groups in Indonesia. Javanese young generations tend to know more about foreign cultures than Javanese cultures so that there is an argument that states "Wong jawa wis ora njawani" which means that there are many Javanese young generations that have abandoned the noble values of Javanese cultures which were inherited by the ancestors of Javanese community. Speech and behaviors of Javanese young generations nowadays do not reflect the Javanese. Hence, to overcome the moral degradation, it is necessary to introduce the local cultures to the young generations.

The overall cultures of human knowledge as a social being are used to understand and interpret the environment and experience as well as guidelines for behaviors [1]. Next,
Yuwana [2] explains that there are cultural groups for pluralistic Indonesian people. The three cultural groups are ethic group or regional group, local general culture, and national culture. Regional culture is the embodiment of community's activities based on social institutions that originate from the ethnic cultures. According to this concept, it can be defined that Javanese cultures are the embodiment of Javanese community's activities based on social institutions that originate from the Javanese cultures. Javanese cultures are very broad including the cultures in Yogyakarta and Surakarta which are the Javanese community's civilization rooted in the palace [3]. Furthermore, Javanese cultures developed in Surakarta and Yogyakarta also have three forms of cultures as suggested by Koentjaraningrat [4] in Mentalitet dan Pembangunan (Mentality and Development) book. One of the ideal forms of Javanese cultures is abstract-only in the mind of Javanese community. Abstract cultures will be concrete if it is actualized. One of the abstract culture actualizations in Surakarta and Yogyakarta community is in the form of Javanese script.

Javanese scripts in Surakarta era are literary works which were developed in the early of Surakarta era and mostly written in Javanese letters by using the new Javanese language. Most literary works developed in the early of Surakarta era were written by recited Java poetry (Tembang). Poerbatjaraka [5] explains that there were two kinds of literary works in Surakarta era namely new literary work and literary development. Literary development is literary work which was created based on the existed literary works, while new literary work was created to divert the hot kingdom political atmosphere to spiritual activities. Surakarta community's lives suffer from physical and mental because of colonialism, and Paku Buwana IV is helpless because of his authorization is conquered. Then, Paku Buwana IV along with other poets wrote books about ethics, morals, guidance, advices, and etc. so that community's condition returned to peace. Besides, there were also many Javanese literary works created by ordinary people in addition to works created by poets. One of the works was "Ngelmi Karoyalan." The script was a result of the author's actualization after seeing the community condition at that time.

"Karoyalan" came from the word "Royal." According to Poerwadarminta [6], royal: seneng mbuwang duwit utawa nglakoni maksiyat. In Indonesian language, the meaning is throwing away money and committing immorality. So, someone who is "royal" is someone whose behaviors deviate 
from religious and cultural rules. Someone who is "royal" shows low characters. Erien Sudewa, as quoted by Anas S and Irwanto A [7] explain that the chaos of Indonesia happens because of the lack of characters. The lack of nation characters is swayed, and if it is constantly ignored, the nation will become a failed state. "Ngelmi Karoyalan" script is an old Javanese work which contains many elements of education, especially education for adults. So, this old Javanese literary work really needs to be understood by the current generations.

Most of Javanese scripts in Surakarta era were written in the form of poetry, including "Ngelmi Karoyalan" script. Hence, in analysing, it is important to know the structure of poetry. Poetry used to write old literary works at the early Surakarta Era was recited Java poetry (Tembang). Poetry is a structure which meaning can be gotten by analysing the meaning in each element which relates to meaning of the other elements in the poetry as a structured system [8]. Moreover, Siswanto [9] explains the characteristic that can be seen at a glance from the form of poetry is the appearance. Typography is the arrangement and the writing of words, rows, and verses in poetry. In conventional poetry, the words are arranged in series and lines. Each row does not necessarily reflect one statement. In line with Javanese poetry in which Hardjawiraga [10] states that a good six-line Java verse form (Tembang Macapat) must be composed based on a certain rule. The Javanese scripts in Surakarta era were one of Javanese works which include guru lagu, guru wilangan, and guru gatra as a metrum. Metrum is the physical structures of recited Java poetry (Tembang). The structures are combined with the inner structures carefully since it is not enough if only physical structures due to the fulfilment of the specified inner rules [11]. Hence, such conventions that contribute poetic effects as well as the relation to the meaning [12]. "Ngelmi Karoyalan" script is an old literary work so that it must be dissected through philology.

Philology is knowledge related to ancient scripts [13]. The old scripts tell or contain matters relating to the texts. Therefore, philology is not only examining the script problems but also discussing the old texts in the script systematically and periodically.

Literary works in its existence are bound by language codes, literary codes, and cultural codes [14]. Javanese literary works in Surakarta era were bound by these codes. In the practice carried out by experts, the study of the old literature will be satisfactorily success if it is filtered by philology since the old literary works were the reflection of culture in that era. There is no support for the literary works, while the writing, language used, and the characteristics of the literary works are different from the present literary works. Most of lay people do not understand or have difficulty in reading and comprehending [15]. Philological theory is used to display script edition in a scientific manner. Since there are printed and handwritten texts in Javanese classical scripts, printed philology is used as the philological approach. Either scripts or prints are seen as cultural products in the form of literary composition which is the expression of messages. The messages in the old literary works carry a certain function that is imagining minds and creating applied norms, either for contemporary people or for future generations [16]. This also the same as the Javanese scripts that contain local wisdoms.

The descriptions of the scripts are based on suggestions from Djamaris [17] which include the name of the script, authors, the age and size of the script, and the script condition. Then, for readers' convenience, critical edition is used as the approach towards the old Javanese scripts since the old Javanese scripts in Surakarta era were transliterated and adapted to the prevailing grammatical rules. According to the base of transliteration in "Ngelmi Kawruh Karoyalan" script with the theory of Paul Maas [18], necessarily modifications, and supplemented with suggestions from Robson [19], there are three things that must be considered in transliteration those are the division of words, spelling, and punctuation.

In order to make the old Javanese scripts become aesthetic and meaningful object, it must be given meaning or wrest the meaning. Teeuw [20] mentions that naturalization, which is an attempt to return deviated things to the clear, understandable, or recuperation, the struggle of meaning. Literary work is a complex and complete structures [21]. Hence, to optimally understand, structural analysis is needed [22]. Structure is permanent links between symptom groups. This links are created by a researcher based on observations [23]. "Ngelmi Karoyalan" script is analysed the constituent elements which meaning can only be grasped if it is viewed as a complete structure.

As the characteristics of literary works in general, Javanese work, including "Ngelmi Karoyalan," there are various kinds of additional convention that attached to the language itself as the first stage of semiotic system. Semiotics is the study of language sign system, codes, signal system, and etc. Semiotics, which is also called symbolism, provides a series of assumptions and concepts that enables the systematic symbolic system. More broadly, semiotics is all human communication in the form of symbols and signs which must be "read." According to North [24], sign is something that exists in someone about something in a certain capacity. Sign is aimed to someone in order to create the same sign or more advanced sign. Pierce's sign classification is re-presentment, objects, and interpretation which are grouped into three dichotomies. From those three dichotomies, the second dichotomy is important since it is the classification of signs that relate to the relationship between re-presentment and objects.

The old Javanese scripts need a deep interpretation so that hermeneutics theory is needed. Etymologically, hermeneutics comes from the word hermeneuein, Greek, which means interpreting. Interpretation is conveyed through language and not the language itself. Literary works need to be interpreted because it consists of language which is full of meaning, either implicit or deliberately implicit [25]. The focus of hermeneutic is more on "understanding" (verstehen). Wilhelm Dilthey as quoted by Budi Darmo [26] explains that interpretation in verstehen aimed at everything that has been achieved so that objects which have been produced by humans in human sciences, such as texts written in the ancient time, can appear and can be felt again in the real life. 
The old Javanese literatures mostly contain "pitutur," "wewarah," so that it also contains educational values. Educational values, literally in $K B B I$ [27], price or there is no definite measurement to determine. Value is something that is useful for humans both physically and spiritually [28]. That opinion is reinforced by Soekanto's opinion [29] that values are the abstractions of personal experience with each other. Values are general guidance that directs behaviours and satisfaction in everyday life. Values also relates to something that is valuable and qualified which show quality and useful for human beings. From some of the opinions, it can be concluded that values are something positive and beneficial in life. Values must be possessed by every human being to gaze phenomena in social life. These values are in the context of ethics (good or bad), logic (right or wrong), and aesthetics (beautiful or ugly).

Educational values consist of values and education. For values, it has been explained above, while education or educate is to maintain or provide training [30]. Education is the process of changing attitudes and behaviours of a person or a group of people in an effort to mature human beings through teaching and training, the process of doing, how to educate. Hadjar Dewantara states that the real success of education is producing civilized people; not those who are intelligent in cognitive and psychomotor but poor in noble characters [31]. Education has a goal to mature students. Adler as followed by Amalia [32] describes education as a process in which all human abilities are influenced by good habits to help themselves and others to achieved good habits. So, education values are the limits of everything that educates toward maturity, either good or bad so that it is useful for life. Educational process does not mean that it can be done in one place and time only. Associated with human existence and life, educational values are directed to the formation of human personalities as individual, social, religious, and cultured beings.

Educational values include: 1) Religious educational values which aim to educate people so that they are better based on religious guidance and always remember God; 2) Moral educational values which aim to educate human beings in recognizing ethical values that is good or bad for actions, actions that must be avoided and must not be avoided so that there is a harmonious relationship between people in the community and the environment. 3) Social educational values which aim to provide awareness to human beings that group lives in family ties between one individual with the others are really needed. 4) Culture educational values which occupy a central and important position within a framework of a culture that is abstract and can be expressed only through observation of more tangible symptoms such as behaviours and material objects as a result of pouring out the concepts of value through patterned actions [33]. The concept of educational values that have been revealed will be used to express the educational values toward "Ngelmi Karoyalan" script although it is not fully used.

Javanese culture is local culture which has different local wisdom from other cultures. Javanese cultures consist of subcultures which have its own characteristics known as local culture. That local culture is the brainchild of Javanese community in the form of local wisdom values. John Haba as cited by Yuwana [34] explains that local wisdom refers to a variety of cultural wealth that grows and develops in society, and it is an important element to strengthen social relations between the communities. Moreover, local wisdom has the following characteristics and functions: 1) markers of group identity; 2) social relationship element; 3) growing from the community itself; 4) gathered in groups; 5) able to change mindset and reciprocal relationship of individuals and groups; 6 ) able to encourage the development of togetherness in order to defend themselves. Besides, the characteristics of local wisdom are also expressed by Moendardjita in Ayatrohaedi [35] that states the elements of potential regional culture as a local wisdom has been tested the surviving abilities with the following characters: 1) able to survive from external cultures; 2) able to accommodate external culture elements; 3) able to integrate the external culture element into the local culture; 4) able to control and direct to the development of culture. Hence, it is clear that local wisdom is knowledge developed by the ancestors in anticipating the environment around them, making the knowledge as a part of culture and introducing as well as continuing from one generation to the other generations. Local wisdom arises when the local culture values begin to be displaced by modernization, as happened to Javanese community nowadays. Local wisdom appraises local values, but it is considered universal [36]. The types of local wisdom are: 1) governance; 2) customary rules; 3) manners and procedures; 4) selection of place and time. That local wisdom is contained in: 1) ancient texts or books; 2) tangible; temple. While the functions are: 1) conservation of nature; 2) knowledge development; 3) development of human resources [37]. Next, Akhmar and Syarifudin [38] explain that local wisdom is a value system or local community's behaviors in interacting with environment wisely. Besides, according to Gobyah in "Berpijak pada kearifan local" [39] explains that local wisdom (local genius) is the truth which has become the tradition in an area. Nevertheless, local wisdom is a combination of the holy values of God's words with various existing values.

Based on the explanation above, local wisdom, in general, can be associated with community life patterns in establishing an individuals' relationship with themselves, social community, nature, and God.

\section{METHOD}

A study entitled Educational Values in A Script "Ngelmi Karoyalan"-A Local Wisdom of Javanese Community uses qualitative method that is a research procedure that results in descriptive data. Nawawii, cited by Siswantoro [40], explains that descriptive method is defined as problem solving procedures that is investigated by describing and illustrating the condition of the research subject or object based on the facts that appear or as they are. The description method in this study is an analytic descriptive method that applies to philology. Ratna [41] explains that analytic descriptive method done by describing the facts that is followed by analysis. The implementation of this method is by describing all external aspects of the script that consist of the name of the script, authors, script condition, script writing, script language, 
and so on as suggested by Edward Djamaris [42], Robson [43], and the texts contained. The way to describe the text is by transliteration which is carried out after an intensive approach to take certain attitudes. To interpret texts in classical Javanese script, hermeneutics method is used. Ratna [44] explains that hermeneutics method does not look for the correct meaning, but the most optimal meaning. In order to avoid infinite interpretation, researchers must have a clear standpoint which is generally done in a spiral motion. With the spiral, giving meaning can be done in depth and directed.

\section{RESULTS AND DISCUSSION}

The result of this study is grouped into three parts based on the research problems. The first part is about educational values in "Kawruh Ngelmi Karoyalan" script. The second part is about local wisdom that is illustrated in "Kawruh Ngelmi Karoyalan" script, and the last part is about educational characters that can be actualized in community's lives as a local wisdom. Before describing the result of the study, it will be first described about the description of "Ngelmi Karoyalan” script.

"Ngelmi Karoyalan" is a Javanese literary work in Surakarta era which was created by ordinary people. This literary work was author's actualization after seeing social culture phenomena that happened in the community at that time. The descriptions of the scripts are stated as follows: "Ngelmi Karoyalan" script is a printed script, and it was printed in 1928 by De Bkiksem in Solo. The name of "Ngelmi Karoyalan" script is on the cover, and the cover is still in a good condition. The writing of the script is Javanese standing letters that consists of 25 pages. The size of the script is $18 \mathrm{~cm}$ $\mathrm{x} 25 \mathrm{~cm}$, and the script is owned personally. "Ngelmi Karoyalan" script is a lesson or education for adults, either men or women.

\section{A. Educational Values in "Ngelmi Karoyalan" Script as A Part of Javanese Local Culture}

It has been explained in the explanation above that educational values are associated with the existence and humans' lives. It is also directed to the formation of humans' personalities as individual, social, religious, and cultured being, so that educational values include: 1) Religious educational values which aim to educate people so that they are better based on religious guidance and always remember God; 2) Moral educational values which aim to educate human beings in recognizing ethical values that is good or bad for actions, actions that must be avoided and must not be avoided so that there is a harmonious relationship between people in the community and the environment. 3) Social educational values which aim to provide awareness to human beings that group lives in family ties between one individual with the others are really needed. 4) Culture educational values which occupy a central and important position within a framework of a culture that is abstract and can be expressed only through observation of more tangible symptoms such as behaviours and material objects as a result of pouring out the concepts of value through patterned actions.

\section{1) Religious Educational Values}

Religious educational values aim to educate people so that they are better based on religious guidance and always remember God. Hence, the religious educational values contained in "Ngelmi Karoyalan" script are: 1) If you are depressed, ask for calmness to God; 2) Human beings always need to pray; 3) Men, who will chase after women, had better use Javanese way that is "praying"; 4) If men approach women, they must be able to meet very often by begging; 5) According to the religion, men who rely their life on women is the same as breaking the syari'ah, and their life is despicable; 6) The knowledge of "Karoyalan" violates the religious; 7) God commands human beings to live in this world for seeking the virtues of life; 8) Humans are dependent to God and only run their lives; 9) Keep praying to God after doing efforts (Hyang Widhi); 10) According to religion, men who are not responsible for the marriage violates the rules; 11) Human beings in this world are dependent to God for seeking the virtues of life.

\section{2) Moral Educational Values}

Moral educational values aim to educate human beings in recognizing ethical values that is good or bad, actions that must be avoided and must not be avoided so that there is a harmonious relationship between people in the community and the environment. Moral education values that revealed in "Ngelmi Karoyalan" script are: 1) Men who always boast money and handsomeness will get bitchy women ( $\mathrm{Jw}$ : wanita lenjeh genjah); 2) Hiring women not by wealth and handsomeness (japa montra) rather by good touching behaviours; 3) Women who want to be approached by men because of money, they only think about worldly, and it is called bitchy women; 4) Men, who are arrogant and always rely on handsomeness and money as well as hiring women as they want, will be shunned; 5) Men who are humble, polite, and well behaved will wins women's heart; 6) Men who only brag money to approach women, if their money runs out, there will be no woman who wants to be approached; 7) Good men whose behaviours are polite, knowing "honour ("unggahungguh"), talking smoothly and attractively will be liked by many women; 8) Women whose moral is depraved will be difficult to be pulled socks up; 9) Women, whose moral is depraved, prefer to like money, eating, sleep, lust, and unsocial. Hence, this kind of women is not allowed to be approached.

\section{3) Social Educational Values}

Social educational values aim to provide awareness to human beings that group lives in family ties between one individual with the others are really needed. In "Ngelmi Karoyalan" script, it can be found that the social educational values are: 1) The relationship between husband and wife can be messy because men are wrong in using money; 2) People must always associate each other, not only if there is a need; 3) People need others' help. 


\section{4) Culture Educational Values}

Culture educational values occupy a central and important position within a framework of a culture that is abstract and can be expressed only through observation of more tangible symptoms such as behaviours and material objects as a result of pouring out the concepts of value through patterned actions. Culture educational values that can be found in "Ngelmi Karoyalan" script are: 1) The author is an abangan-a person who is not a strict follower of one's declared religion-very little knowledge of Islam and Buddhism; 2) Javanese people who have "royal" habit always squander money to find many women; 3) Masher men will suffer syphilis in their old ages; 4) Approaching women by knowing "Ngelmi Karoyalan” will get better results; 5) Approaching honorable women who never go out from home will need others' help; 6) Marrying honorable women must be based on customary; 7) Men who know "Ngelmi Karoyalan" knowledge will be easier in finding the desired women.

\section{B. Local Wisdom in "Ngelmi Karoyalan" Script}

Local wisdom, in general, can be associated with community life patterns in establishing an individuals' relationship with themselves, social community, nature, and God. Local wisdoms that can be found in "Ngelmi Karoyalan" text are: 1) "Ngelmi Karoyalan" script is intended for mature Javanese people, and they do not like people who boast their good looking and wealth; 2) Javanese community really hate people who spend money for hiring women; 3) Masher men will suffer syphilis and become destitute in their old ages; No one wants to be occupied; 4) Men, who seek women with money, will not get true love; 5) Women who are already "depraved" will be difficult to be pulled socks up and forbidden to be approached; 6) Javanese community really hate women who work as bitches; 7) Javanese community do not like women who do not want to work at home, and their job is only dress themselves up to pursue men.

Those Javanese local wisdoms are appropriate to be applied to Javanese community's lives nowadays.

\section{CONCLUSION}

"Ngelmi Karoyalan" script is a printed script which is printed out in 1928 by De Bkiksem in Solo. The name of "Ngelmi Karoyalan" exists in the cover which is still good looking. The writing of the script is Javanese standing letters that consists of 25 pages. The size of the script is $18 \mathrm{~cm} \mathrm{x} 25$ $\mathrm{cm}$, and the script is owned personally. "Ngelmi Karoyalan" script is a lesson or education for adults, either men or women, who are starting to like each other. The main contents of this script are about the ways to approach women and the ways to be romantic. Besides, it also gives Javanese traditional lesson about how to marry honorable women.

The educational values that stand out are religious educational values and moral educational values which are appropriate as a "guidance” script.
The overall local wisdoms of Javanese community that are illustrated in "Ngelmi Karoyalan" script are suitable for Javanese community’s lives nowadays.

\section{REFERENCES}

[1] S. Yuwana Sudikan, Metode Penelitian Kebudayaan. Surabaya: Citra Wacana, 2000, pp.2.

[2] S. Yuwana Sudikan, Metode Penelitian Kebudayaan. Surabaya: Citra Wacana, 2000, pp.4-5.

[3] Koentjaraningrat, Kebudayaan Jawa. Jakarta: PN Balai Pustaka, 1984, pp. 25 .

[4] Koentjaraningrat, Kebudayaan, Mentalitet dan Pembangunan. Jakarta: Gramedia, 1974.

[5] R.M. Poerbatjaraka, Kapustakaan Jawa. Batavia: JB. Wolters, 1957, pp.128.

[6] W.J.S. Poerwadarminta, Baoesastra Djawa. Batavia: J.B. Wolters, 1933, pp. 535.

[7] A. Salahudin, I. Alkrienciehie, Pendidikan Karakter Pendidikan Berbasis Agama dan Budaya Bangsa, Bandung: Pustaka Setia, 2013, pp.31.

[8] Siswantara, Metode Penelitian Sastra. Yogyakarta: Pustaka Pelajar, 1987, pp.13.

[9] Siswanto, Wahyudi, Pengantar Teori Sastra. Jakarta: PT Grasindo, 2008, pp.113.

[10] Hardjawiraga, Pethikan Ngekaraken. Jakarta: Balai Pustaka, 1952.

[11] J. Herman Waluyo, Teori Apresiasi Sastra. Jakarta: Erlangga, 1987, pp. 12.

[12] A. Teeuw, Sastra dan Pengantar ilmu Sastra. Jakarta. Pustaka Jaya, 1984, pp.11.

[13] B.S. Purnomo, Filologi dan Studi Sastra Lama. Surabaya: Bintang Surabaya, 2007, pp.1.

[14] A. Teeuw, Sastra Baru Indonesia I. Flores: Nusa Indah, 1978, pp.12.

[15] S. Wahyu Widayati, ”Seksualitas menurut masyarakat Jawa: Kajian Filosofis terhadap Teks Serat Kawruh Sanggama,” Laporan Penelitian. Departemen Pendidikan Nasional, Republik Indonesia. Universitas Negeri Surabaya. Lembaga Penelitian, 2001.

[16] Baried, Siti Baroroh dkk, Pengantar Teori Filologi. Pusat Pembinaan dan Pengembangan Bahasa Jokdjakarta: Depdikbud, 1985, pp.4-5.

[17] E. Djamaris, Filologi dan Cara Kerja Penelitian Filologi. Jakarta: Pusat Pembinaan dan Pengembangan Bahasa Departemen Pendidikan dan Kebudayaan, 1977, pp.23.

[18] M. Paul, Textual Criticism. Oxford: The Claredon Press. Terjemahan dari Bahasa Jerman oleh Barbara Flower, 1958.

[19] S.O. Robson, "Pengkajian Sastra-Sastra Tradisional Indonesia. Bahasa dan Sastra,” Pusat Pembinaan dan Pengembangan Bahasa, Tahun VI., No. 6, 1978, pp.31.

[20] A. Teeuw, Membaca dan Menilai Karya Sastra. Jakarta. Gramedia, 1983, pp.4.

[21] Hawkes, Turrance, Structure and Semiotics. London: Methuen \& Co. Ltd, 1976, pp.16.

[22] Hill, Knoxc, Intrepeting Literature. Chicago: the University Press of Chicago, 1866, pp.16.

[23] Hardoko, Dick, Pengantar Ilmu Sastra. Jakarta: PT Gramedia, 1984, pp.36.

[24] N. Winfrid. Handbook of Semiotics. Bloomington: Indian University Press, 1990, pp.42.

[25] Ratna, Nyoman Kutha, Penelitian Sastra. Yogyakarta: Pustaka Pelajar, 2007.

[26] Darmo, Budi, Pengantar Teori Sastra. Jakarta: Pusat Bahasa, 2004, pp.109.

[27] Depdikbud, Kamus Besar Bahasa Indonesia. Jakarta: Balai Pustaka, 1982, pp.615.

[28] E.M. Setiadi, Ilmu Sosial dan Budaya Dasar. Jakarta: Kencana, 2006 pp.117. 
[29] S. Soekanto, Pribadi dan Masyarakat (Suatu Tujuan dan Sosiologis). Bandung: Alumni, 2003, pp.161.

[30] Depdikbud, Kamus Besar Bahasa Indonesia. Jakarta: Balai Pustaka, 1982, pp.240.

[31] Wibowo, Manajemen Kinerja. Jakarta: Rajawali Pers, 2013, pp.35.

[32] N. Rihi Amalia, Analisis Gaya Bahasa dan Nilai-Nilai Pendidikan Novel Sang Pemimpi Karya Andrea Horata. Thesis. Surakarta: Program Pendidikan Bahasa dan Sastra Indonesia UNS, unpublished, 2010.

[33] Dian, Nilai-Nilai Pendidikan.

https//griyawardani.wordpress.com/2011/05/19/nilai-nilai pendidikan/, 2011.

[34] S. S. Yuwana Sudikan, Kearifan Budaya Lokal. Sidoarjo: Damar, 2013, pp.7.

[35] Ayatrohaedi, Kepribadian Budaya Bangsa (Local Genius). Jakarta: Dunia Pustaka Jaya, 1986, pp.40-46.

[36] Bali Pos. http://www. Balipos.co.id, didonwnload 17/9/2003.

[37] N. Norhandayani. Pengertian Kearifan Lokal. http://naninorhandayani.Blogspot.com/2011/05, 2011.
[38] Akhmar, Syarifudin, Kearifan Lokal Lingkungan Masyarakat. jejakjejak hijau.blogspot coid/2012/01/Kearifan Lokal Lingkungan Masyarakat, 2012.

[39] Gobyah, I Ketut, ”Berpijak Pada Kearifan Lokal”, www.balipos.co.id, 3 -3-2013.

[40] Siswantoro, Metode Penelitian Sastra Analisis Struktur Puisi. Yogyakarta: Pustaka Pelajar, 2011, pp.56.

[41] Ratna, Nyoman Kutha, Penelitian Sastra. Yogyakarta: Pustaka Pelajar, 2007, pp.53.

[42] E. Djamaris, Filologi dan Cara Kerja Penelitian Filologi. Jakarta: Pusa Pembinaan dan Pengembangan Bahasa Departemen Pendidikan dan Kebudayaan, 1977.

[43] S.O. Robson, "Pengkajian Sastra-Sastra tradisional Indonesia. Bahasa dan Sastra,” Pusat Pembinaan dan Pengembanagn Bahasa, Tahun VI, No. 6, 1978.

[44] Ratna, Nyoman Kutha, Penelitian Sastra. Yogyakarta: Pustaka Pelajar, 2007, pp.47. 